\title{
BIULETYN TEOLOGII LAIKATU (133)
}

ZAWARTOŚĆ: I. Europejskie Spotkanie Młodych w Bazylei.*

\section{EUROPEJSKIE SPOTKANIE MŁODYCH W BAZYLEI}

(28 XII 2017 - 1 I 2018)

\section{Program spotkania}

28 grudnia 2017 r. w Bazylei rozpoczęło się 40. Europejskie Spotkanie Młodych, organizowane przez ekumeniczną Wspólnotę z Taizé. Polacy stanowili jedną czwartą wśród 20 tys. uczestników tego wydarzenia, które trwało do 1 stycznia. Ponieważ Bazylea leży na styku granic Szwajcarii, Francji i Niemiec, po raz pierwszy w historii tych dorocznych spotkań młodzi pielgrzymi byli goszczeni przez mieszkańców trzech krajów.

Oprócz Polaków, których było 4,9 tys., do najliczniej reprezentowanych narodów należeli: Ukraińcy (2,8 tys.), Niemcy (1,5 tys.), Francuzi (1,3 tys.), Chorwaci (1,3 tys.) i Włosi (1,2 tys.). W sumie w spotkaniu wzięli udział przedstawiciele 45 krajów. Aż 95 proc. z nich przyjęły rodziny w Bazylei i okolicy. W organizacji spotkania pomagało 1000 wolontariuszy z całej Europy. Uczestnicy spotkania zostali skierowani do 95 punktów przyjęć, obejmujących ponad 200 parafii i wspólnot chrześcijańskich w Bazylei i okolicy, oraz na terenie Szwajcarii, Francji i Niemiec. Do Bazylei przyjechało w sumie 270 autokarów z różnych stron Europy. Dla młodych pielgrzymów przygotowano 50 tys. porcji posiłków, w których znalazło się m.in. 7 ton chleba, 52,5 tys. jabłek, 75 tys. mandarynek i 55 tys. butelek wody.

Przeor Wspólnoty z Taizé, br. Alois, zwócił uwagę, że spotkanie odbywa się w położonej w sercu Europy „bogatej i sytej” Bazylei. Jest to nie tylko miasto, ale także region transgraniczny i będzie to ważny aspekt

* Redaktorem Biuletynu teologii laikatu jest Czesław P a r z y s ze k SAC, Warszawa. 
spotkania. Młodzi uczestnicy spotkania „powinni doświadczyć, że w Europie istnieją regiony, w których wspólnota ponad granicami stała się już czymś oczywistym i to będzie kontynuowane". Zakonnik nawiązał też do związków między aktualnym ,zmęczeniem Europy” i „wyparowaniem wiary" w niektórych częściach Europy. Podkreślił, że na Kościołach spoczywa odpowiedzialność za to, by młodzi ludzie „na nowo, głębiej i bardziej osobiście" mogli żyć wiarą. ,Jedziemy do Bazylei, ponieważ jest to także miasto reformacji, ale nie reformacji luterańskiej, tylko Kościoła reformowanego [kalwińskiej - KAI]. Teraz, pod koniec tego roku, kiedy tak dużo mówiło się o reformacji z okazji jej jubileuszu 500-lecia, chcemy ponownie dać przykład, że chrześcijanie razem mogą robić o wiele więcej niż dotychczas. Wciąż żyjemy podzieleni. Możemy jednak częściej spotykać się na wspólnej modlitwie i jasno stwierdzić, że Chrystus już dziś nas łączy, mimo że wiele kwestii teologicznych wciąż jest otwartych" - mówił przeor Wspólnoty.

W programie 40. Europejskiego Spotkania Młodych oprócz wspólnych modlitw przewidziano też warsztaty tematyczne z zakresu duchowości, poznawania Kościoła, problemów społecznych, relacji między sztuką i wiarą. Na wspólne posiłki oraz modlitwy wieczorne organizatorzy wynajęli dwie hale sportowe przy stadionie St. Jakob-Park.

Dzień rozpoczynać się będzie poranną modlitwą w parafii goszczącej uczestników, spotkaniami z osobami zaangażowanymi w życie lokalnej wspólnoty oraz rozmowami w małych grupach inspirowanymi listem br. Aloisa, zatytułowanym Niewyczerpana radość. Jest on owocem jego podróży do Dżuby i do Rumbeku w Sudanie Południowym, oraz do Chartumu, stolicy Sudanu, a wcześniej pielgrzymki do Egiptu. „Wracając z Afryki, powiedzieliśmy sobie: Głos osób ciężko doświadczonych - mieszkających daleko od nas, albo tuż obok - jest tak słabo słyszany. To tak, jakby ich wołanie ginęło w próżni. To, że słyszymy je przez media, nie wystarczy. Jak odpowiedzieć na nie naszym życiem?" - pisze w nim przeor Wspólnoty. I przedstawia cztery „propozycje na rok 2018”, które „są w części inspirowane tym pytaniem”: „Iść w głąb do źródeł radości”, „Usłyszeć wołanie najsłabszych”, „Dzielić trudne doświadczenia i radości” oraz „Wśród chrześcijan cieszyć się darami, które mają inni”.

W południe młodzi spotykali się na wspólnej modlitwie w kościołach w centrum Bazylei. Po południu (29 i 30 grudnia) prowadzone były warsztaty tematyczne, uczestnicy spotkania dzielili się też informacjami o swoim zaangażowaniu w miejscach, z których pochodzą, we wspólnotach 
kościelnych, szkołach, uczelniach i w miejscach pracy. Zaplanowano także warsztaty na temat dialogu międzyreligijnego i form współpracy ponad granicami. Dzień kończyła wieczorna modlitwa w halach sportowych, połączona z rozważaniem wygłoszonym przez br. Aloisa.

Tematy warsztatów były bardzo zróżnicowane i podzielone na cztery grupy. Pierwsza dotyczy duchowości, np.: „Radość według św. Pawła”, „Bliski Boga i bliski ludzi. Spotkanie z Mikołajem z Flüe (1417-1487), mistykiem i twórcą pokoju”, „Wiara i nauka - konflikt czy wzajemne uzupełnianie się?”, „Wierzyć inaczej, iść razem. Dialog jako droga ku spokojnemu współistnieniu" - z udziałem przedstawicieli judaizmu, islamu i chrześcijaństwa. Druga grupa tematyczna dotyczyła Kościoła, np.: „Cieszyć się z darów innych”, „Małe wspólnoty tymczasowe”, „Chwalić Boga tańcem i bębnami” - spotkanie z Kościołami afrykańskimi. Trzecia grupa dotyczyła solidarności i spraw społecznych, np.: „Podążać za pasją, wybrać karierę”, „Jak konkretnie rozwijać styl życia bardziej szanujący środowisko naturalne?”, „Zrobić razem coś sensownego przeciwko pustce w codzienności uchodźców”, „Handel ludźmi i współczesne niewolnictwo”, „Dlaczego mam coraz mniej czasu?", a czwarta zaś - związków między sztuką i wiarą, np.: zwiedzanie wystawy dzieł Marka Chagalla z lat 1911-1919, wizyta z przewodnikiem w katedrze w Bazylei.

31 grudnia po południu zamiast na warsztatach, młodzież zebrała się w grupach narodowych. Po modlitwie wieczornej wróciła do goszczących ją parafii na czuwanie modlitewne w intencji pokoju na świecie, a następnie na „Święto narodów”. 1 stycznia uczestnicy spotkania w Bazylei wzięli udział w porannej celebracji w parafiach, a następnie zjedli obiad z goszczącymi ich rodzinami, po czym wyruszyli w drogę powrotną do swych krajów.

\section{Przesłanie papieża Franciszka}

„Ojciec Święty Franciszek cieszy się, że postanowiliście uczestniczyć w tym spotkaniu, aby przyjąć i zgłębić przesłanie Jezusa. Ono jest źródłem radości dla wszystkich, którzy otwierają na nie swoje serce" - czytamy w watykańskim przesłaniu na 40. spotkanie młodzieży zorganizowane przez ekumeniczną Wspólnotę z Taizé. W imieniu Franciszka wystosował je kard. Pietro Parolin, który odnosi się do tematu tegorocznego spotkania, a mianowicie do niewyczerpanej radości, która wypływa z Ewangelii. „Papież zachęca was - napisał kardynał - abyście pozwolili zamieszkać w sobie tej radości, która rodzi się z żywej przyjaźni z Jezusem i która 
nigdy nie zamyka nas na innych i na cierpienia tego świata. Franciszek prosi was, byście byli zjednoczeni z Panem przez modlitwę i słuchanie Jego słowa. Niech On pomoże wam wykorzystywać wasze talenty dla rozwoju kultury miłosierdzia, w oparciu o odkrycie spotkania z innymi: kultury, w której nikt nie patrzy na drugiego obojętnie lub odwraca wzrok, gdy widzi cierpienie innych".

Kardynał Parolin nawiązał też do obchodzonego niedawno 500-lecia reformacji. „Papież modli się do Ducha Świętego, aby pomagał wam młodzi protestanci, katolicy i prawosławni - radować się i wzbogacać różnorodnością darów, które otrzymali wszyscy uczniowie Chrystusa, aby pokazać, że radość Ewangelii nas jednoczy ponad wszelkimi ranami, które nas dzielą. Franciszek zachęca was również, byście nie bali się iść po drogach braterstwa, aby wasze spotkanie w Bazylei uwidoczniło radosną jedność, która wypływa z przeobfitego serca Pana" - napisał kardynał w watykańskim przesłaniu na spotkanie młodzieży w Bazylei.

\section{Wywiad Doroty Abdelmoula (KAI) z br. Aloisem}

- Na progu Nowego Roku zaprasza Brat młodych ludzi, by tematem i inspiracja najbliższych miesięcy uczynili „,niewyczerpana radośc”. Skąd taki wybór?

- Ponieważ jest to radość wynikająca $\mathrm{z}$ wiary, z bycia kochanym przez Boga, to wreszcie radość Bożego Narodzenia: radość Maryi i Boga, który raduje się, że zamieszkał wśród nas. Jeśli nie będziemy pogłębiali w nas tej radości, istnieje ryzyko, że zaczniemy traktować ją jako wysiłek do podjęcia, a nie dar otrzymany z niebios. Ryzykujemy, że będziemy pogrążeni w strachu, będziemy się bronić - tak jak np. młodzi, przed którymi jest tyle trudności, lęków, którzy nie są w stanie zaplanować swojej przyszłości. Radość, to antidotum na zwątpienie i lęk!

- Mówiac o wyzwaniach, stojących przed wspótczesna mlodzieża, często opowiada Brat o swoich ostatnich spotkaniach z młodymi mieszkańcami Afryki i Bliskiego Wschodu. Jak, jako Europejczycy i chrześcijanie, powinniśmy odpowiedzieć na wyzwania, z którymi się mierza?

- Przede wszystkim trzeba lepiej poznać tych ludzi i całą sytuację. Dwa lata temu spędzałem Boże Narodzenie w Syrii. Potem byłem w Libanie, a w kończącym się roku odwiedziłem m.in. mieszkańców Sudanu Południowego, starając się wsłuchać w sytuację mieszkańców tych terenów. 
Zbyt długo myśleliśmy, że te kraje Afryki i Bliskiego Wschodu są daleko od nas. Tymczasem, one są u naszych drzwi! Wielkie wyzwanie, jakim są migranci, których będzie wśród nas coraz więcej - to niezwykle trudna rzeczywistość. I jeśli będziemy do niej podchodzić z lękiem i postawą obronną, nie znajdziemy rozwiązania.

Proponuję, by w nowym roku każdy młody człowiek nawiązał osobisty kontakt z jednym z uchodźców. Niekoniecznie po to, by od razu pomagać mu materialnie, ale by wsłuchać się w jego historię, by wziąc ją sobie do serca i uczynić przedmiotem modlitwy. Bez tego osobistego kontaktu nie znajdziemy drogi do podjęcia tego wyzwania.

- Taki kontakt jest już nawiązywany w Taizé, gdzie od wielu miesięcy mieszka grupa migrantów z Afryki. Jaka przyszłość ich czeka?

- Oni sami nie umieją odpowiedzieć na to pytanie. Są zagubieni. Na razie integrują się ze społeczeństwem francuskim i być może w przyszłości, kiedy zobaczą, że zdaje to egzamin, zechcą pozostać u nas. Nie mają dalekosiężnych planów. Po prostu chcą być przyjęci, wysłuchani, a my jesteśmy zadziwieni tym, jak bardzo lokalne społeczeństwo wychodzi im na spotkanie i nas wspiera.

- Nie jest to jedyna inicjatywa, podejmowana przez Wasza wspólnotę. $W$ ostatnich dniach zachęca Brat m.in. do udziatu w pielgrzymce i spotkaniu młodzieży azjatyckiej, które odbędzie się latem przyszłego roku w Hongkongu. Dlaczego wybór akurat tego miejsca? Azja, to przyszłość, czy teraźniejszość Kościoła?

- W Azji jest wiele krajów, w których wiara niezwykle się rozprzestrzeniła, ale są też takie, w których chrześcijanie stanowią mniejszość i mierzą się z trudnościami. Dlatego ważne jest, byśmy wyruszyli z Europy na spotkanie z nimi. Abyśmy towarzyszyli im w poszukiwaniu tego, jak żyć wiarą, jak przebaczać i budować pokój.

W Hongkongu spotkają się m.in. młodzi z Japonii, Korei i Chin. Wiemy z historii, że relacje między tymi narodami były naznaczone wielkim cierpieniem, a pojednanie jeszcze nie całkiem się dokonało. To chrześcijanie są odpowiedzialni za doprowadzenie do tego pojednania.

- Czy ta odpowiedzialność dotyczy też Europy, która - choć zbudowana na chrześcijańskich fundamentach - cierpi obecnie z powodu glębokich podziatów i odejścia od jedności opartej na wierze i wspólnych wartościach? 
- Oczywiście. Chrześcijanie są odpowiedzialni za budowanie większej jedności w Europie i są też do tego uzdolnieni. A jedność między chrześcijanami może pomóc w dalszym budowaniu wspólnoty europejskiej.

- Jednym z wyzwań chrześcijan w najbliższych miesiacach będzie też Synod Biskupów na temat młodzieży i rozeznawania powołania. Co powie Brat uczestnikom tego zgromadzenia i samemu papieżowi, jeśli będzie miat ku temu okazje??

- Spotkałem papieża Franciszka trzykrotnie podczas prywatnych audiencji i za każdym razem dziękowałem mu za jego odwagę i otwartość na młodych, na ekumenizm. On także bardzo mnie zachęca do dalszego towarzyszenia młodzieży. Myślę, że to właśnie towarzyszenie jest niezwykle ważne, a w Kościele powinniśmy jeszcze bardziej się zastanawiać, jak towarzyszyć młodym ludziom. Kardynał Lorenzo Balidesseri, który przewodniczy Sekretariatowi Synodu Biskupów, był w lecie w Taizé. Odbyliśmy wiele rozmów, on sam spotykał się też często z młodzieżą. Naprawdę, bardzo się cieszymy, że ten Synod się zbliża.

- Dziękuję za rozmowę.

\section{Usłyszeć wołanie ubogich}

Na potrzebę słuchania wołania ubogich zwrócił uwagę w swoim drugim rozważaniu podczas 40. Europejskiego Spotkania Młodych w Bazylei przeor ekumenicznej wspólnoty z Taizé, br. Alois. Nawiązał do swojej październikowej wizyty w Sudanie Południowym i w Sudanie.

Zaznaczył, że Sudan Południowy przeżywa chwile wielkich trudności, które wywołują pesymizm wśród wielu osób. Nie mają już nadziei. Kraj cierpi z powodu galopującej inflacji, pensje nie są wypłacane od wielu miesięcy, rozpowszechnia się przemoc, a w obiegu jest wiele broni. „U sióstr Matki Teresy widziałem matki przynoszące niedożywione dzieci. Czasami dziewięcioletnia lub dziesięcioletnia dziewczynka przynosi młodszego brata. Aby pójść na rynek, aby coś sprzedać, te matki w wielkim upale idą całymi dniami, przenosząc towar na głowie i trzymając niemowlę w skórzanych pasach z koźlej skóry" - powiedział przeor Taizé. W następnym tygodniu, spędzonym w Sudanie, wielkie wrażenie wywarła na braciach matka Samira, jednego z młodych uchodźców, który goszczony był w Taizé. Przybył on po bardzo trudnej podróży, a wkrótce potem niespodziewanie dostał ataku serca i zmarł. Pozostali młodzi uchodźcy zajęli się jego 
pogrzebem wraz z imamem naszego regionu. „W Sudanie opowiedziałem o tych wydarzeniach jego matce. Przy każdym zdaniu kiwała głową «Al hamdulillah - chwała Bogu». Potem mi wyjaśniła: «Był moim jedynym synem. Mój mąż mnie zostawił. Jestem chora. Sprzedałam dom, żeby zapłacić za podróż Samira»". I ta muzułmańska kobieta dodała słowa, które Biblia umieszcza w ustach Hioba: «Dał Pan i zabrał Pan. Niech będzie imię Pańskie błogosławione!»” - podkreślił br. Alois.

Przeor ekumenicznej wspólnoty z Taizé podkreślił, że również w Europie nie brak ludzi zranionych przez życie. Przypomniał, że Chrystus, stawszy się człowiekiem, zjednoczył z każdą istotą ludzką, szczególnie z najbardziej opuszczoną. „To, co czynimy najmniejszym - czynimy dla Niego. Gdy słyszymy w pobliżu wołanie istoty poranionej, kiedy patrzymy w oczy, kiedy słuchamy, kiedy dotykamy tych, którzy cierpią, zbliżamy się do Jezusa ubogiego. Biedni sprawiają, że wkraczamy w większą zażyłość z Nim. Czyż najbardziej ubodzy nie wnoszą niezastąpionego wkładu w budowanie społeczeństwa bardziej braterskiego? Ujawniają nam naszą własną słabość. Przez to czynią nas bardziej pokornymi, bardziej ludzkimi" - powiedział br. Alois.

\section{Wolanie o radość i o pokój}

Jak przypominali uczestnikom spotkania bracia z ekumenicznej Wspólnoty z Taizé, istotą europejskich spotkań, organizowanych każdego roku w innym miejscu w Europie, jest to, że wspólnie tworzą one kolejne etapy Pielgrzymki Zaufania przez Ziemię, w której młodzi biorą udział, by modlić się o pokój na świecie i pojednanie między ludźmi. Apel ten mocno wybrzmiał także w Bazylei nie tylko w wygłaszanych naukach, ale przede wszystkim w postawie młodych pielgrzymów, którzy spędzali długie godziny na modlitwie w intencji pokoju.

Młodzi, pytani o motywację do udziału w spotkaniu, często wspominali właśnie o modlitwie o pokój, jako intencji, która osobiście jest im bliska i w której chcą się modlić. Podkreślali też, że pokój jest tą wartością, która łączy ich ponad różnymi podziałami. Także duże zainteresowanie popołudniowymi warsztatami, których tematyka była częściowo związana właśnie $\mathrm{z}$ budowaniem pokoju na świecie, świadczy o tym, jak bliski jest ten temat młodzieży, która do Bazylei przyjechała z blisko 50 krajów, nie tylko europejskich. W szwajcarskim spotkaniu wzięli udział także 
przedstawiciele Meksyku, Chile, Brazylii, Paragwaju, Gambii, Haiti i Stanów Zjednoczonych.

„Niezwyciężona radość” - to temat trwającego w Bazylei spotkania, ale też myśl przewodnia listu, który przeor ekumenicznej wspólnoty z Taizé, br. Alois skierował do młodzieży świata na rok 2018, wraz z propozycjami duszpasterskimi. Podkreślił w nim, że inspiracja do podjęcia tego tematu płynie z niedawnych spotkań z dziećmi i młodymi ludźmi, którzy mimo ciężkich chorób czy dzieciństwa spędzanego w obozach uchodźców zachowują prawdziwą radość pochodzącą od Boga.

„Chcielibyśmy, żeby podobne świadectwa przyświecały nam, kiedy podejmujemy trwającą przez cały rok refleksję na temat radości, jednego $\mathrm{z}$ trzech fundamentów, które - razem z prostotą i miłosierdziem - br. Roger umieścił w centrum naszej wspólnoty z Taizé" - napisał do młodzieży br. Alois. Podzielił się też swoją radością spotkania z uchodźcami i chrześcijanami z Bliskiego Wschodu, m.in. podczas ubiegłorocznej wizyty w Egipcie, gdzie bracia wraz z młodzieżą gościli w ekumenicznej Wspólnocie Anafora.

W rozmowie z przedstawicielką KAI br. Alois wyjaśnił, że praktykowanie chrześcijańskiej radości jest powinnością chrześcijanina. „Jeśli nie będziemy pogłębiali w nas tej radości, istnieje ryzyko, że zaczniemy traktować ją jako wysiłek do podjęcia, a nie dar otrzymany z niebios. Ryzykujemy, że będziemy pogrążeni w strachu, będziemy się bronić - tak jak np. młodzi, przed którymi jest tyle trudności, lęków, którzy nie są w stanie zaplanować swojej przyszłości” - powiedział.

\section{„Ekumenizm w praktyce”}

Jak podkreślały polskie wolontariuszki, które przez wiele miesięcy pracowały w Bazylei, przygotowując spotkanie młodych, fakt, że wszystkich uczestników spotkania udało się zakwaterować w rodzinach, to nie tylko sukces logistyczny, ale przede wszystkim wielkie dzieło ewangelizacyjne. „Bardzo szybko po naszym przyjeździe zorientowałyśmy się, że kościoły są tu puste, a wiara utożsamiana jest ze starszymi ludźmi” - wyjaśniały Polki. Podkreślały też, że Szwajcarzy nie mieli zwyczaju przyjmowania pielgrzymów w swoich domach, a ich gościnność świadczy o przemianie serc, która już się dokonała.

Także młodzi pielgrzymi opowiadają o „ekumenizmie w praktyce”, którego wcześniej nie doświadczali. Pięć punktów przyjęć, obejmujących ok. 200 parafii i wspólnot chrześcijańskich, to w dużej części także Kościoły 
protestanckie, a pielgrzymi goszczeni byli często przez ewangelików bądź też rodziny, których członkowie przynależą do różnych wspólnot Kościoła.

O ciągłe pogłębianie ekumenicznych więzi apeluje także papież Franciszek. W jego imieniu - o czym wspominaliśmy już - list do uczestników spotkania wystosował watykański sekretarz stanu, kard. Pietro Parolin.

Bazylea jest także postrzegana jako przykład budowania dobrych relacji między narodami, które niegdyś toczyły ze sobą spory. W specjalnym liście do organizatorów i uczestników 40. Europejskiego Spotkania Młodych, napisał o tym prezydent Rzeczypospolitej Polskiej, Andrzej Duda: „To przykład, który ilustruje ważną prawdę, że pokojowe współistnienie w Europie jest jedyną drogą rozwoju wszystkich krajów i wszystkich narodów, tworzących wielką europejską rodzinę. Wiedział o tym dobrze Brat Roger, który był świadkiem okrucieństw II wojny światowej. Założona przez niego wspólnota jest żywym świadectwem, że dialog jest możliwy, że chrześcijańskie korzenie Europy wciąż mogą być źródłem inspiracji”.

\section{Wołanie o pomoc cierpiącym i uchodźcom}

W rozważaniach, którymi każdego wieczoru podczas wspólnej modlitwy br. Alois dzielił się z uczestnikami spotkania młodych, były poruszające wspomnienia z wizyty m.in. w Sudanie Południowym. Doświadczenia tego pobytu - krzyk bólu rodzącego się z nędzy, przemocy, skrajnej słabości, której byli świadkami w Afryce - pragnął przekazać młodym Europejczykom przybyłym do Bazylei. „Postawiłem też sobie pytanie: co zrobić, aby ten krzyk został wysłuchany, aby ludzie, którzy cierpią, nie mieli już wrażenia, że ich płacz zatraca się w próżni?" - wyznał br. Alois.

W rozmowie z przedstawicielką KAI przeor ekumenicznej wspólnoty zachęcał do podjęcia konkretnych kroków w celu pomocy potrzebującym. Przede wszystkim jednak apelował o poznanie ich potrzeb oraz sytuacji, które może zaowocować skuteczną, udzielaną z miłości, pomocą.

\section{Apel o krzewienie braterstwa}

W obliczu zagrożeń dla pokoju, takich jak kryzys migracyjny i wyzwania ekologiczne, konieczne jest krzewienie braterstwa - powiedział podczas ostatniej modlitwy wieczornej 40. Europejskiego Spotkania Młodych w Bazylei przeor ekumenicznej wspólnoty z Taizé - br. Alois. Była ona poświęcona szczególnie kwestii pokoju. 
Przeor Taizé wskazał, że do głównych wyzwań stojących dziś przed ludzką rodziną należy kryzys migracyjny spowodowany wieloma czynnikami: wojnami i niepewnością, skrajnym ubóstwem i brakiem jakichkolwiek perspektyw na przyszłość, ale także zakłóceniami klimatu. „W ich trudnej sytuacji ludzie ci potrzebują solidarności i, jak już doświadczyliśmy w Taizé, mogą zostać naszymi przyjaciółmi” - powiedział br. Alois. Zaznaczył, że Chrystus zachęca nas do wyjścia poza nasze lęki i uprzedzenia, bo jest pasterzem całej ludzkości, umarł także za niechrześcijan. Drugim wyzwaniem wskazanym przez przeora Taizé był kryzys ekologiczny i zakłócenia klimatu. Zaapelował do odpowiedzialnych za decyzje polityczne i gospodarcze, aby istniejące środki przeznaczyć na eliminację ubóstwa i troskę o środowisko.

Następnie br. Alois wskazał na konieczność krzewienia coraz większego braterstwa. Zaznaczył, że w tym celu konieczne jest otwieranie się na inne kultury i mentalności. Podkreślił, że zacząć trzeba w najbliższym otoczeniu. „Po powrocie do domu wyjdźmy zza swoich barier, porozmawiajmy z myślącymi inaczej, budujmy mosty: między religiami, miedzy regionami, między krajami europejskimi, między kontynentami. Pójdźmy do osób najbardziej pokrzywdzonych. Pozwólmy na przykład, żeby bezdomny opowiedział nam swoją historię, albo porozmawiajmy z kimś niepełnosprawnym, z chorym, z uchodźcą. I zobaczymy, jak otwierają się nasze serca, poszerzają, stają się bardziej ludzkie, a nawet odkryjemy radość". Zabierzmy więc z tego spotkania w Bazylei słowa: „Istota ludzka jest stworzona do radości, a radości nie można zachować dla siebie, trzeba się nią dzielić. Radość, której źródłem jest miłość Boga, ta radość nigdy się nie wyczerpie, ona jest ukrytym bodźcem do niesłabnącego działania na rzecz innych ludzi" - zakończył swoje rozważanie br. Alois. 